УДК 340.13

DOI https://doi.org/10.32850/sulj.2019.4.2.19

\title{
РОЛЬ СИСТЕМОУТВОРЮЮЧИХ СПЕЦІАЛІЗОВАНИХ НОРМАТИВНИХ ПРИПИСІВ У МЕХАНІЗМІ ПРАВОВОГО РЕГУЛЮВАННЯ
}

Суханова Д. С.

У статті розглядається проблема спеціалізованих норм права як необхідного і важливого складника механізму правового регулювання. Визначається їх природа, обгрунтовується наявність у них загальних ознак, притаманних нормі права, аналізуються специфічні ознаки чієї групи норм. Аналізуються місце та роль даної групи норм у системі спеціалізованих норм. Обгрунтовується поділ системоутворюючих норм на види залежно від їх функціонального призначення і виділення таких видів норм, як декларативні норми, норми-принципи, норми-дефініції.

Ключові слова: норма права, спеціалізована норма, декларативна норма, норма-принцип, дефінітивна норма.

В статье рассматривается проблема специализированных норм права как необходимого и важного элемента механизма правового регулирования. Определяется их природа, обосновывается наличие у них общих признаков, присущих любой норме права, анализируются специфические признаки рассматриваемой группы норм. Анализируются место и роль рассматриваемой группы норм в системе специализированных норм. Обосновывается деление системообразующих норм на виды в зависимости от их функционального назначения и выделение таких видов норм, как декларативные нормы, нормы-принципы, нормы-дефиниции.

Ключевые слова: норма права, специализированная норма, декларативная норма, норма-принцип, дефинитивная норма.

The article is devoted to the problem of specialized legal norms as a necessary and important element of the mechanism of legal regulation. Their nature is determined, their common features are justified by any rule of law specific features of the group of norms are analyzed. According to the group of norms in the system of specialized norms are analyzed their place and role. The division of system-forming norms into species is substantiated, depending on their functional purpose. System-forming specialized norms determine and form a system of law and link its elements. This group of specialized norms consist of declarative norms, norms-principles and definitive norms. Thus, declarative norms fix the "general" "basic" principles of law. As a rule, norms-principles are contained in the preambles of normative legal acts. The bulk of such norms is concentrated in the constitution as the basic law of the state. A special functional purpose of norms in question is expressed in the fact that they do not directly regulate the behavior of subjects, but integrate generally valid, moral, political, ideological values into legal matter, and give these values a legal form. Legal principles differ from declarative norms both in the form of their expression and in their functional purpose. It is in the norms - principles find their development the ideological foundations expressed in legal declarations. A significant role in determining and shaping the system of law is played by definitive norms. So, normative definitions explain the content and meaning of the terms used in the text of a normative legal act. Also, they perform the function of clarifying the meaning of the terms used in the act. System-forming rules of law are the most common in the system of specialized norms. Without their binding, formative influence, the system of law could hardly exist.

Key words: rule of law, specified norm, declarative norm, norm-principle, definitive norm.

Постановка проблеми та її актуальність. Усебічне осмислення юридичної природи нетипових правових приписів неможливе без виокремлення та систематизації істотних особливостей їх окремих різновидів. Це дозволяє детально проаналізувати властивості кожного виду нетипових правових приписів, а також створює реальні передумови для подальшого ґрунтовного вивчення їх місця у механізмі правового регулювання.

Підсумовуючи результати осмислення різних поглядів, слід зазначити, що правові приписи, що закріплюють, наприклад, декларативні, дефінітивні або оперативні норми прямого правила поведінки, зазвичай не формулюють, проте виступають як загальне правило, зразок узаконеного припису, моделюючи зміст і характер правового регулювання загалом. Таким чином, визначення спеціалізованих правоположень як норм права не суперечить існуючому в юридичній науці підходу до поняття норми права.

Сказане дає підставу вважати, що правові декларації, правові принципи, правові дефініції можуть бути досліджені як норми права, які мають поруч із «класичним» (типовими) ознаками, що притаманні нормам права, ряд специфічних властивостей.

Аналіз останніх досліджень і публікацій. Безпосередньому дослідженню юридичних властивостей нетипових правових приписів присвятили наукові праці С. АлексєєВ, В. Бабаєв, А. Баранов, С. Бобровник, М. Власенко, Ж. Дзейко, А. Колодій, Ю. Кривицький, О. Кузнецова, О. Мурашин, Н. Пархоменко, С. Погребняк, О. Скакун, І. Фаршатов, В. Федоренко, О. Черданцев та інші.

Метою цієї статті $\epsilon$ розвиток та узагальнення теоретичних знань про нетипові правові приписи як необхідний і важливий елемент механізму правового регулювання, а також акцентування уваги саме на декларативних, дефінітивних нормах та нормах-принципах.

Виклад основного матеріалу. На підставі узагальнення різних науково-теоретичних позицій стосовно характеристики нетипових правових приписів можна констатувати, що в системі права існує особливий різновид спеціалізованих норм, які представляють собою приписи, що закріплюють базові основи правової дійсності, визначають принципи існуючого суспільного ладу, моральні, політичні, ідеологічні основи законодавства тощо [1, с. 22]. Системоутво- 
рюючі норми права $є$ найбільш загальними в системі спеціалізованих норм. Зазначені спеціалізовані норми визначають, формують систему права, об'єднують норми у єдине ціле, в єдину систему, зв'язують іï елементи, визначають їх місто в системі. Без їх впливу навряд чи змогла $б$ існувати система права.

На переконання О. Кузнецової, всі спеціалізовані норми цивільного права володіють класичною двохелементною структурою норми-припису [2, с. 15], також спеціалізовані норми в системі цивільного права призначені виконувати різні функції, котрі можуть бути поділені на три групи: системоутворюючі, системоспрощуючі та системозберігаючі [2, с. 6, 14]. На думку С. Алексєєва, ці узагальнюючі спеціалізовані норми права органічно входять у нормативну частину механізму правового регулювання [3, с. 242], виконуючи функцію «цементуючого» засобу в його структурі [4, с. 320]. В цьому контексті С. Алексєєв акцентує увагу саме на нормах-принципах, декларативних і дефінітивних нормах. Запропонований С. Алексєєвим підхід до розуміння спеціалізованих норм права знайшов підтримку серед сучасних фахівців. Так, С. Бобровник наголошує на тому, що важливим критерієм класифікації норм права $€$ можливість виокремлення саме спеціалізованих юридичних норм [4, с. 223]. Зазначену групу спеціалізованих норм складають декларативні норми, норми-принципи та дефінітивні норми [5, с. 111].

Враховуючи викладене, перейдемо до детальної характеристики такого виду спеціалізованих норм, як декларативні правові норми. Варто наголосити на тому, що питання юридичної природи декларативних норм права належить до дискусійних. У юридичній енциклопедичній літературі під декларативними нормами права розуміють норми, що не містять конкретних правил поведінки, а визначають цілі, завдання, принципи окремих галузей права, правових інститутів, предмет, форми та засоби правового регулювання [6, с. 22]

Так, норми-декларації як окремий різновид спеціалізованих норм права надають загальний цілеспрямований характер правореалізаційному процесу [5, с.113]. На переконання А.С. Піголкіна та М.М. Вопленка, до авторитета правових декларацій звертаються під час підзаконної правотворчості, розроблення інтерпретаційних актів, вирішення складних і принципових юридичних справ за умов нетипової ситуації у правозастосовній діяльності, тобто за таких обставин, коли пізнання загальної спрямованості законодавства $\epsilon$ потрібною умовою наступної правомірної поведінки [7, с. 15].

Декларативні норми представляють собою приписи, які закріплюють основні базиси правової дійсності, основи існуючого суспільного ладу, загальні моральні, політичні, ідеологічні засади правового регулювання. Зазвичай такі норми містяться в преамбулах нормативно-правових актів [8, с. 161-162]. Основна маса таких норм зосереджена в конституції як основному законі держави. Яскравим прикладом може виступати Конституція України, в якій у лаконічній формі проголошуються основні положення, які знаходять свій розвиток у вигляді правових принципів у відповідних статтях Конституції України. Окрім того, декларативні норми можуть також бути закріплені безпосередньо у статтях конституцій. Прикладом може слугувати стаття 1 Конституції України. Привертає увагу з цього приводу приклад декларативної норми, який наво- дить у своїй роботі Ю. Кривицький. Так, КС України в п. 3.1. мотивувальної частини Рішення від 6 жовтня 2009 р. N 24-рп/2009 у справі за конституційним поданням Київської обласної ради щодо офіційного тлумачення положення ст. 9 Закону України «Про правовий режим території, що зазнала радіоактивного забруднення внаслідок Чорнобильської катастрофи» посилається на норму-декларацію, що закріплена у преамбулі відповідного закону [5, с. 123-124].

Вираження декларативних норм у практиці реальних правовідносин через акти дотримання, виконання, використання та застосування права. I тільки після цього означені норми права втілюються в суспільне життя, переводяться в площину конкретних суб'єктивних прав та юридичних обов'язків [5, с. 125-126]. При цьому М.М. Вопленко зазначає, що норми-декларації можуть здійснюватися й безпосередньо як інформаційно-правові й ідеологічно-правові установки правосвідомості учасників правових відносин. Зокрема, це відбувається у правороз'яснювальній діяльності слідчого, прокурора, судді, коли останні, наприклад, пояснюють завдання кримінального права (ст. 1 Кримінального кодексу України), кримінального провадження (ст. 2 Кримінально-процесуального кодексу України) обвинуваченому, потерпілому та ін. У подібних випадках правові декларації допомагають зробити правильну оцінку юридичних явищ і прийняти рішення, що відповідає «букві» та «духу» чинного законодавства [7, с. 10]. Також як приклад цього різновиду спеціалізованих норм права можна навести норму-декларацію, що закріплена у ст. 1 цПК України: «Завданнями цивільного судочинства $€$ справедливий, неупереджений та своєчасний розгляд і вирішення цивільних справ з метою захисту порушених, невизнаних або оспорюваних прав, свобод чи інтересів фізичних осіб, прав та інтересів юридичних осіб, інтересів держави» [11].

Беручи до уваги розглянуте вище, перейдемо до огляду особливостей реалізації декларативних норм. Особливість реалізації норм-декларацій полягає в багатоступеневості процесу перетворення їх у реальне життя. Здебільшого перед тим як втілитися в конкретних суб'єктивних правах та обов'язках, досягнути правового ефекту, вони повинні бути переведені на рівень основних юридичних норм. Це здійснюється шляхом правотворчої, а в необхідних випадках і правороз'яснюючої деталізації або конкретизації, що $€$ першим ступенем їх реалізації [10, с. 229]. Так, Ю. Кривицький резюмує, що роль декларативних норм у механізмі правового регулювання зводиться до такого: 1) вони зміцнюють смислову єдність і погодженість механізму правового регулювання, сприяють одноманітності під час правового впорядкування суспільних відносин; 2) декларативні норми спрямовують, орієнтують і корегують правотворчу, правореалізаційну, правозастосовну діяльність, діють на формування правосвідомості суб'єктів права, виступаючи як нормативно-ціннісні орієнтири їхньої поведінки; 3) норми-декларації обов'язково враховуються під час усунення прогалин у праві, тлумачення юридичних норм, особливо при телеологічному (цільовому) та системному способах тлумачення, у процесі встановлення, оцінки ефективності правового регулювання суспільних відносин; 4) формуючи відповідний образ механізму правового регулювання, вони виступають як 
«ввідні» юридичні норми, які полегшують знайомство 3 конкретною галуззю чи інститутом права; 5) декларативні норми сприяють глибшому проникненню в суть нормативно-правового акта, зокрема, розумінню того, чому й для чого він прийнятий [5, с. 154-156].

Норми-принципи представляють собою особливий різновид системоутворюючих правових норм. Вони відрізняються від декларативних норм як формою свого виразу, так і функціональним призначенням. Саме в нормах-принципах ідеологічні основи, що виражені в декларативних нормах, знаходять свій розвиток [9 с. 16]. Так, на думку О.Ф. Скакун, норми-принципи - це норми, в яких сформульовані незаперечні вимоги загального характеру, що стосуються всіх або більшості інститутів або норм галузі права [12, с. 289]. Вираження ключових ідей, що пронизують увесь зміст права, високий ступінь загальності й інші функціональні та формальні особливості дають підстави розглядати норми-принципи як окремий різновид спеціалізованих норм. Прикладом норми-принципу $\epsilon$ нормативне правило (положення), закріплене в ч. 1 статті 19 Конституції України: «Правовий порядок в Україні ґрунтується на засадах, відповідно до якого ніхто не може бути примушений робити те, що не передбачено законодавством» [13].

У той же час, як особливий різновид спеціалізованих правових норм, вони володіють і рядом специфічних рис, як-от: особлива імператівність і безумовність правових приписів, що закріплюють принципи права; відображення найважливіших економічних, соціально-політичних, ідеологічних засад суспільства, що відповідають рівню його історичного розвитку; вони виступають орієнтирами вдосконалення системи права і систематизації законодавства; надають однаковість всій системі правових норм, забезпечують єдність правового регулювання суспільних відносин; мають вищу юридичну силу порівняно з іншими нормами, безпосередньо встановлюють правило поведінки [9, с. 16-17].

Перейдемо до розгляду наявності підстав для віднесення дефінітивних норм до класу спеціалізованих. Одразу доречно зазначити, що нормативні дефініції трактуються як важливе правове явище в межах різних підходів, включаючи концепції нормативно-правових приписів, вихідних норм права, нетипових або нестандартних нормативних приписів тощо. Разом із тим С. Алексєєв під дефінітивною нормою права як різновидом спеціалізованої розуміє норму, що призначена для закріплення в узагальненому вигляді ознак певної правової категорії [3, с. 319]. Цей погляд на сутність норм-дефініцій підтримує більшість сучасних правознавців. Дефініції, закріплені в нормативних правових актах, становлять найважливішу групу правових дефініцій. Ïх називають легальними. Якщо доктринальні й буденні дефініції виражають світоглядну сутність, здатні швидко змінюватися і досить нестабільні з погляду їх «зберігання» в часі, то нормативні правові визначення статичні. Їх стабільність визначається самою природою права. Нормотворчі дефініції становлять основу правового регулювання. [14, с. 16-23].

Безумовно, значення дефінітивних норм у юридичній практиці важко переоцінити, оскільки вони слугують важливими моментами встановлення єдності в розумінні та реалізації правоустановчих і правоохоронних норм. Нетотожність сутності основних норм права $\epsilon$ аргументом, який дозволяє інтерпретувати нормативні дефініції як самостійний вид спеціалізованих норм права. Так, норми-дефініції не входять до складу основних юридичних норм, що безпосередньо регулюють суспільні відносини, тобто без них останні можуть «безперешкодно» функціонувати. У цьому полягає субсидіарно-регулятивна природа норм-дефініцій [5, с. 113]. Водночас останні спрямовані на забезпечення, підтримку єдності й одноманітності механізму правового регулювання. Отже, наявні достатні підстави для кваліфікації дефінітивних норм як окремого виду спеціалізованих норм права, що характеризуються сукупністю специфічних ознак [5, с. 114]. Значення дефінітивних нормативних приписів у механізмі правового регулювання полягає у забезпеченні єдності в розумінні й реалізації всіх велінь законодавця; підвищенні ступеня формалізації законодавства; формуванні понятійного апарату системи права; впровадженні в чинне законодавство нових результатів розвитку науки, відновленні теоретичної бази законодавства.

Проведений аналіз наявних наукових позицій вчених щодо природи спеціалізованих норм права надає підстави резюмувати, що сьогодні відсутня єдина, загальноприйнятна точка зору на сутність та види спеціалізованих норм права. Виходячи з проаналізованого вище, можна дійти висновку, що декларативні норми права, норми-принципи та норми-дефініції відповідають усім змістовим, функціональним і формальним ознакам спеціалізованих норм права. 


\section{Література}

1. Баранов А.В. К вопросу о понятии и месте специализированных норм в системе российского права. Вестник Омского университета. Серия «Право». 2017. № 1 (50). C. 22-30.

2. Кузнецова О.А. Специализированные нормы гражданского права: теоретические проблемы : автореф. дис. на соискание учен. степени докт. юрид. наук : спец. 12.00.03 «Гражданское право; предпринимательское право; семейное право; международное частное право». Екатеринбург, 2007. 43 с.

3. Алексеев С. С. Общая теория права : учеб. / С. С. Алексеев. 2-е изд., перераб. и доп. Москва : Проспект, 2009. 576 c.

4. Загальна теорія держави і права: (основні поняття, категорії, прав. конструкції та наук. концепції) : навч. посіб. / [О. Л. Копиленко, О. В. Зайчук, А. П. Заєць та ін.]; за ред. О. В. Зайчука, Н. М. Оніщенко. Київ : Юрінком Інтер, 2008. 400 c.

5. Кривицький Ю.В. Спеціалізовані норми права в механізмі правового регулювання : дис...канд.юрид. наук : 12.00.01. Київ, 2010. 260 с.

6. Юридична енциклопедія: В 6 т. / Редкол: Ю.С. Шемшученко (голова редкол.) та ін. Київ : Укр. енцикл., 1998. Т. 2 : Д - Й. 1999. 744 с.

7. Вопленко Н.Н. Реализация права: учеб. пособ. Волгоград : Изд-во Волгоград. государ. ун-та, 2001. 48 с.
8. Козюбра Н.И. Социалистическое право и общественное сознание ; Отв. ред. : Бабий Б.М. Москва : Наукова думка, 1979. 207 с.

9. Баранов А.В. Системоопределяющие специализированные нормы современного российского права. Вестник Омского университета. Серия «Право». 2017. № 4 (53). С. 13-19.

10. Нормы советского права: Проблемы теории / [В.К. Бабаев, М.И. Байтин, В.М. Баранов и др.]; под ред. М.И. Байтина, В.К. Бабаева. Саратов : Изд-во Саратов. ун-та, 1987. 248 с.

11. Цивільний процесуальний кодекс України від 18 березня 2004 р. No 1618-IV. URL: https://zakon.rada.gov.ua/laws/show/1618-15.

12. Скакун О.Ф. Теорія права і держави : підруч. Київ : Алерта ; КНТ ; ЦУЛ, 2009. 520 с.

13. Конституція України від 28 червня 1996 р. No 254k/96-BP. URL: http://zakon1.rada.gov.ua/cgibin/ laws $/$ main.cgi?nreg=254\%EA\%2F96-\%E2\%F0\#Find.

14. Дашковька О. Правові дефініції як різновид нормативних приписів. Загальні проблеми правової науки. Вісник №3 (70). URL: http://dspace.nlu.edu.ua/ bitstream/123456789/3918/1/Dashkovska_16.pdf

Суханова Д. С., кандидат юридичних наук, доцент кафедри державно-правових дисциплін Одеського державного університету внутрішніх справ 